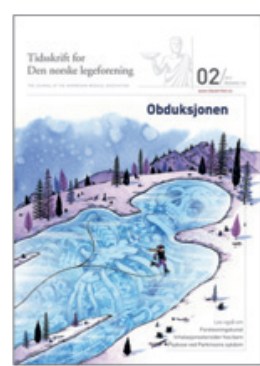

\section{Redd for pasienterfaringer?}

I Tidsskriftet nr. 2/2012 mener Stine Bjerkestrand at bloggermakt og kampanjejournalistikk har bevist at folket har makt til å sette politisk dagsorden, definere hvordan en sykdom skal forstås og påvirke fordelingen av forskningsmidler (1). Artikkelen tar utgangspunkt i kronisk utmattelsessyndrom (CFS/ME). Bjerkestrand hevder at pasienter med kronisk utmattelsessyndrom har «etablert seg som en pressgruppe» som «jevnlig [kommenterer] lenker til stoff om tilstanden» (1). Dette forstår jeg som en negativ holdning til at bloggere som selv har kronisk utmattelsessyndrom skal kunne gi uttrykk for hva de mener om behandlingstilbud og forskningsresultater. Videre sier Bjerkestrand at bloggerne har sørget for «viral spredning av Fluge og medarbeideres artikkel». Hun påpeker også at de ikke har noen «profesjonsetisk forpliktelse eller tradisjon for å fremme nyansert etisk debatt» (1). Etter min mening er dette det samme som å si at pasienter ikke har rett til å ha synspunkter basert på egen erfaring.

I Nasjonal helse- og omsorgsplan 2011-2015 gis det i omtalen av den nye pasientrollen honnør til bloggere og det at de kan bidra til å sette tema for samfunnsdebatten. Jeg har i mange år i mine daværende stillinger i Sosial- og departementet og Helsedirektoratet hatt kontakter med familier og enkeltpersoner med sjeldne og lite kjente diagnoser. De fleste har opplevd manglende forståelse fra helsetjenesten for hva det innebærer å ha den aktuelle lite kjente diagnosen. Det samme gjelder også pasienter med kronisk utmattelsessyndrom. Etter hvert som kunnskapen om sjeldne tilstander har økt er dette for noen grupper blitt mye bedre, men ikke for alle. Selv om årsaken til mange sjeldne og lite kjente tilstander er ukjent, får de fleste nødvendig bistand fra kommunens omsorgstjenester. Slik er det i meget liten grad for dem som har alvorlig grad av kronisk utmattelsessyndrom. Dette kommer frem i en relativt fersk undersøkelse fra SINTEF (2).

Pasienter med uforklarlig langvarig utmattelse, smerter, søvnvansker, konsentrasjonsvansker o.l. møtes med skepsis og får anbefaling fra legen om å ta seg sammen, trene og gå til kognitiv terapi. Ofte mangler det medisinsk utredning, bl.a. fordi kjennskapen til de diagnostiske kriteriene er liten blant fastlegene (2).
Erfaringsbasert kunnskap og brukermedvirkning er nedfelt $i$ lover, strategier og retningslinjer. Ifølge $\S 3-1$ i pasient- og brukerettighetsloven har pasienten rett til medvirkning (3). Når det gjelder brukermedvirkning fra representanter for pasienter med kronisk utmattelsessyndrom, registrerer jeg at dette ikke aksepteres av miljøer som for øvrig snakker varmt om brukermedvirkning. Er det provoserende for forskere og leger at pasientene har mot til å påstå at de blir dårligere av anbefalt behandling?

Etter min mening illustrerer Maktskiftet manglende forståelse for hva som ligger i den nye pasientrollen og hvilke forpliktelser helsepersonell har til å bidra til reell brukermedvirkning. Hvordan kan behandlingen av sykdommer med uklar eller ukjent årsak bli bedre hvis ingen vil høre på pasienterfaringene?

\section{Lisbeth Myhre}

Stabekk

Lisbeth Myhre (f. 1945) er fysiolog (cand.real.). Hun er pensjonist, men har arbeidserfaring fra bl.a. sykehus, Universitetet i Oslo, Legemiddelkontrollen og Sosial- og helsedepartementet og var i årene 2002-11 avdelingsdirektør i Helsedirektoratet.

Ingen oppgitte interessekonflikter

\section{Litteratur}

1. Bjerkestrand S. Maktskiftet. Tidsskr Nor Legeforen 2012; 132: 125

2. Lippestad JW, Kurtze N, Bjerkan AM. Status for helse- og omsorgstilbudet til pasienter med CFS/ ME i Norge. SINTEF-rapport. Oslo: SINTEF, 2011. www.sintef.no/Publikasjoner-SINTEF/Publikasjon/ ?pubid $=$ SINTEF \pm A17571 (22.2.2012)

3. LOV 1999-07-02 nr. 63: Lov om pasient- og brukerrettigheter (pasient- og brukerrettighetsloven). www.lovdata.no/all/hl-19990702-063.html (22.2.2012).

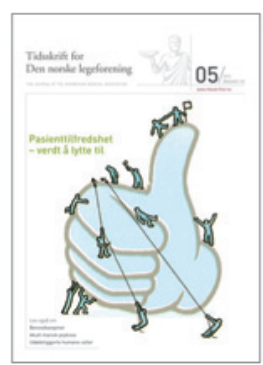

\section{Nødvendig maktskifte?}

Annette Giljes respons i Tidsskriftet nr. $5 / 2012$ (1) føyer seg inn i rekken av flere liknende reaksjoner jeg har fătt i sosiale medier på lederartikkelen Maktskiftet (2). Mange ønsker å fortelle meg at gradert trening ikke virker, at jeg ikke lytter til pasientenes erfaringer og at jeg ikke anerkjenner Fluge og medarbeideres forskning.

Jeg er ikke lege og tar derfor heller ikke i lederartikkelen stilling til behandling av kronisk utmattelsessyndrom (2). Jeg har kun pekt på at det finnes ulike alternativer, hvorav ett har fått svært mye oppmerksomhet i både sosiale og «tradisjonelle» medier, og at dette har gitt gjennomslag.

Reaksjonene Maktskiftet er blitt møtt med, bidrar til å illustrere mitt poeng om mediemakt. Trykket i sosiale medier fra den ene siden i denne polariserte debatten har vært tankevekkende. Det har gitt meg ny forståelse for dem som både i mediene og direkte til meg har sagt at de ikke lenger orker å delta. Når man tillegges meninger man ikke har og deretter stilles til veggs for disse, blir reell meningsutveksling vanskelig og motivasjonen for å delta lav. Analysen i lederartikkelen har vist seg å være mer presis enn jeg var klar over på forhånd.

\section{Stine Bjerkestrand}

Tidsskriftet

Stine Bjerkestrand (f. 1972) er utviklingsredaktør i Tidsskriftet og cand.mag. med journalistikk, medievitenskap og statsvitenskap i fagkretsen.

Ingen oppgitte interessekonflikter.

\section{Litteratur}

1. Gilje A. Maktskifte er nødvendig. Tidsskr Nor Legeforen 2012; 132: 510

2. Bjerkestrand S. Maktskiftet. Tidsskr Nor Legeforen 2012; 132: 125.

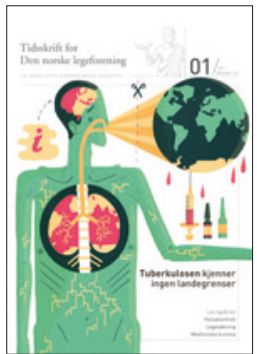

\section{Bivirkning av behandling}

I Tidsskriftet nr. 1/2012 skriver Knut-Arne Wensaas en oppfølgingssak (1) til artikkelen som ble publisert i Gut i 2011 (2). Det slo meg at det ble hoppet bukk over en viktig årsaksfaktor til både irritabel tarmsykdom og kronisk utmattelse: Det ble ikke korrigert for terapien. Hvor er gruppen med påvist giardiainfeksjon som ikke fikk antibiotisk behandling eller som fikk restituert tarmfloraen med effektive, levende probiotika etter behandlingen (3)?

I min 30-årige praksis har jeg sett veldig mange pasienter med diagnosen irritabel 
tarmsykdom og/eller kronisk utmattelse som hadde allergi mot Candida albicans etter en kraftig antibiotikakur. Min mistanke om at ikke bare irritabel tarmsykdom (4), men også kronisk utmattelsessyndrom er en autoimmun sykdom, fikk ny næring etter de spennende forskningsresultatene fra Mella og medarbeidere (5).

Jeg vil på ingen måte påstå at alle former for irritabel tarmsykdom og/eller kronisk utmattelse skyldes en immunologisk reaksjon bare mot sopper. Selvfølgelig kan også andre mikrober, mat og tungmetaller være triggere til autoimmune reaksjoner. Men det er en viktig differensialdiagnose.

Det jeg etterlyser, er bevis på Wensaas' påstand om at det er infeksjon med Giardia lamblia og ikke en bivirkning av en (ufullstendig) behandling som er årsaken til funnene i studien (2). Og jeg tillater meg å spørre om de $54 \%$ som ikke utviklet irritabel tarmsykdom eller kronisk tretthet, hadde tatt effektive tarmbakterier etter antibiotikakuren.

Pasienter som lider av kronisk utmattelse, fortjener å få det beste av forskning, diagnose og behandling som helsevesenet har å tilby.

\section{Heiko Santelmann}

heiko@online.no

Oslo
Heiko Santelmann (f. 1950) er allmennpraktiserende lege med spesialkompetanse i sammensatte lidelser. Han har forskererfaring fra Institutt for allmennmedisin ved Universitetet i Oslo, med professor Even Lærum som veileder.

Ingen oppgitte interessekonflikter.

\section{Litteratur}

1. Wensaas K-A. Giardiainfeksjon kan gi irritabel tarm og kronisk utmattelse. Tidsskr Nor Legeforen 2012; 132: 27

2. Wensaas K-A, Langeland N, Hanevik K et al. Irritable bowel syndrome and chronic fatigue 3 years after acute giardiasis: historic cohort study. Gut 2012; 61: 214-9

3. Valeur J, Berstad A, Midtvedt T. Intestinal autointoksikasjon-fortsatt aktuell sykdomsmekanisme? Tidsskr Nor Legeforen 2011; 131: 1875-6.

4. Santelmann H, Howard JM. Yeast metabolic products, yeast antigens and yeasts as possible triggers for irritable bowel syndrome. Eur J Gastroenterol Hepatol 2005; 17: $21-6$.

5. Fluge $\varnothing$, Bruland O, Risa K et al. Benefit from Blymphocyte depletion using the anti-CD20 antibody rituximab in chronic fatigue syndrome. A doubleblind and placebo-controlled study. PLOS ONE 2011; 6: e26358

\section{RETTELSER}

$\varnothing k t$ hvilepuls - økt risiko for hjerted ød

Erlend Hem

Tidsskr Nor Legeforen 2012; 132: 282

I Tidsskriftet nr. 3/2012 s. 282 under bildet skal det stå:

Foto Lasse Berre

Vi beklager feilen. Den er rettet i nettutgaven.

Faste stillinger må på plass

Hege Gjessing

Tidsskr Nor Legeforen 2012; 132: 561

I presidentens leder i Tidsskriftet nr. 5/2012 skal ingressen være:

Det er på tide å gjenta budskapet om at det ikke er akseptabelt at mer enn $90 \%$ av legene som spesialiserer seg har midlertidige ansettelser.

Vi beklager feilen. Den er rettet i nettutgaven. 